Bangladesh J. Bot. 47(4): 839-846, 2018 (December)

\title{
GROWTH, YIELD AND BIOCHEMICAL RESPONSES OF BARI CHHOLA-9 (CICER ARIETINUM L.) TO GA ${ }_{3}$ AND RHIZOBIUM APPLICATION
}

\author{
TASNia JaHAN, Farhana Islam Khan, AMM Golam AdAM* \\ and Hasna Hena Begum
}

Department of Botany, Jagannath University, Dhaka-1100, Bangladesh

Keywords: Chhola, Growth, Yield, Biochemical response, Gibberellic acid, Rhizobium

\begin{abstract}
A field experiment was conducted to investigate the responses of various concentrations of $\mathrm{GA}_{3}(10,20$, $50 \mathrm{ppm}$ ) and Rhizobium inoculation on growth, yield and biochemical parameters of BARI Chhola-9. Foliar application of 50 ppm GA 3 resulted maximum plant height, number of primary branches per plant, shoot and root length, fresh and dry weight of shoot and root and biomass duration per plant with significant variations in case of fresh and dry weight of shoot and biomass duration. The stimulatory effect of $50 \mathrm{ppm} \mathrm{GA}_{3}$ on number of pods per plant, fresh and dry weight of pods per plant, number of seeds per pod, number of seeds and straw yield per plant and weight of 1000 -seed eventually produced $4.76 \%$ higher yield over the control. Yield parameters of BARI Chhola-9 showed almost negative response to Rhizobium and $10 \mathrm{ppm}$ treatments with a few exceptions. Pigment content of leaves also increased due to $50 \mathrm{ppm} \mathrm{GA}_{3}$ treatment at both vegetative and flowering stages where, significantly higher amount of chlorophyll a and $b$ were recorded from flowering stage although statistically similar to $20 \mathrm{ppm} \mathrm{GA}_{3}$ treatment. However, protein content of leaves increased following Rhizobium and 10 ppm GA 3 treatments at vegetative stage and to all treatments at flowering stage but, increase in protein content of seeds was recorded from Rhizobium treatment only. Out of four treatments, $50 \mathrm{ppm}$ produced better yield.
\end{abstract}

\section{Introduction}

Chhola (Cicer arietinum L.) is one of the important pulse crops for its nutritive seeds. In terms of area covered by pulses it occupies third position in Bangladesh. Seeds contain $25.3-28.9$ protein, 38 - 59 carbohydrate, 3.0 fibre, 4.8 - 5.5 oil, 0.2 calcium, and $0.3 \%$ phosphorus. Digestibility of protein varies from $76-78 \%$ and carbohydrate from $57-60 \%$ (Hulse1991). Leaves also contain 4 - 8\% protein. The per capita consumption of pulses in Bangladesh is only 13.29 g per day, while the World Health Organization suggests 45 g per day (BBS 2011). It has been estimated that the demand of pulse requirement will be increased to about 3 million metric tons in the year of 2020 (Golder et al. 2014). There are many methods which may help to increase the pulse production where the use of growth promoting substances and organism are considered as one of the best way. Deficiency of these substances at any stage of plant growth may create a barrier in attaining maximum yield. Moreover, these substances can improve the physiological efficiency including photosynthetic ability and can enhance the effective partitioning of accumulates from source and sink in the field crops. Therefore, research on the effect of growth promoting substances as well as organism on economically important crop plants are of primary concern for a large number of plant physiologists and agronomists all over the world.

Investigations all over the world showed that $\mathrm{GA}_{3}$ at appropriate concentrations had beneficial effect on different parameters of economically important plants viz., green gram (Akbari et al. 2008), mungbean (Abdel and Al-Rawi 2011), chickpea (Thakare et al. 2011 and Mazid 2014), tomato (Kumar et al. 2014), cowpea (Nabi et al. 2014), china aster (Kumar et al. 2015). On the other hand, plant growth promoting bacteria (PGPB) play pivotal role in plant growth by producing

*Author for correspondence: <adam_du04@yahoo.com>. 
phytohormones, fixing $\mathrm{N}_{2}$ asymbiotically, solubilizing inorganic phosphate, mineralizing organic phosphate and supplying nutrients (Dey et al. 2004). Findings of Bashan and de-Bashan (2005) revealed that a good number of bacterial genera viz., Acinetobacter, Alcaligenes, Arthrobacter, Azospirillium, Azotobacter, Bacillus, Beijerinckia, Burkholdria, Enterobacter, Erwinia, Flavobacterium, Serroti, mostly associated with the rhizosphere, are found to be beneficial for crop growth, yield and quality. The stimulating effects of inoculation of seeds with Rhizobium alone or in combination with other growth bacteria have also been reported by many authors in various important crops including Chhola (Hoque and Haq 1994, Rabbani et al. 2005, Togay et al. 2008, Nishita and Joshi 2010, Ogutcu et al. 2010).

In Bangladesh, although very few experiments had been taken up with chhola using Rhizobium inoculation (Bhuiyan et al. 2008 and Zaman et al. 2011) but, research work using GA on any variety of chhola is also scanty. Thus, an attempt was made to study the effect of $\mathrm{GA}_{3}$ and Rhizobium inoculation on the growth, yield and biochemical responses of BARI Chhola-9.

\section{Materials and Methods}

A field experiment was conducted during the year of 2015-2016 at the botanical garden of the Department of Botany, Jagannath University, Dhaka-1100. A high yielding variety, BARI Chhola-9 used for this investigation was released in the year of 2011. The initial properties of soil was analysed following standard methods for the determination of required doses of fertilizers (Murphy and Riley 1962, Jackson 1973). The experiment was laid out in RBD with three replications for each treatment. The total area of the experimental field was $35 \mathrm{~m}^{2}$. Seeds and Rhizobium strain (Rhizobium BARI Rca 259) were collected from BARI. The experiment was consisted of 5 treatments viz., $\mathrm{T}_{0}=$ Distilled water (Control), $\mathrm{T}_{1}=$ Seed treated with Rhizobium BARI Rca 259, $\mathrm{T}_{2}=10 \mathrm{ppm} \mathrm{GA}, \mathrm{T}_{3}=20 \mathrm{ppm} \mathrm{GA}_{3}, \mathrm{~T}_{4}=50 \mathrm{ppm} \mathrm{GA}_{3}$. Seeds were sterilized with $0.05 \%$ calcium hypochlorite solution and soaked in distilled water for $12 \mathrm{hrs}$. But, in case of bacterial treatment seeds were surface-sterilized with $95 \%$ ethanol and then aseptically germinated in Petri dishes containing $20 \mathrm{ml}$ of deionized water for 5 days at $25^{\circ} \mathrm{C}$ in a growth chamber. The germinated seeds were treated with $2 \mathrm{ml}$ bacterial culture $\left(10^{8} \mathrm{cell} / \mathrm{ml}\right)$. Seeds were sown on December 14, 2015 maintaining row to row distance of $40 \mathrm{~cm}$ and seed to seed distance of $10 \mathrm{~cm}$. Cultural practices (thinning, irrigation, weeding etc.) and fertilizer application were done following Hand Book of Agricultural Technology (Chowdhury and Hassan 2013) and Fertilizer Recommendation Guide (2012). Urea as a source of nitrogen was not used in case of bacterial treatment. Gibberellic acid was applied as foliar spray in sunny early morning at the age of 35 days.

Chlorophyll a, b, carotenoid and protein contents of leaves were determined at vegetative and flowering stages. Protein content of seeds was also determined after harvest. The amount of chlorophyll a and b was determined by using specific absorption co-efficient of Mckinney (1940) and the formulae of Maclachalan and Zalik (1963). The amounts of carotenoid was calculated using the equation of von Wettstein (1957). The method of Lowry et al. (1951) was employed for the determination of protein content of leaves and seeds. Plants were harvested at the age of 112 days. Nine plants from each treatment were harvested separately to record data on different growth and yield parameters. Data were analyzed statistically and treatment means were compared by LSD test at 5\% level of significance (Steel et al. 1997).

\section{Results and Discussion}

Results showed that plant height increased due to Rhizobium inoculation and $50 \mathrm{ppm} \mathrm{GA}_{3}$ treatments where, the maximum height was recorded from 50 ppm $\mathrm{GA}_{3}$ treatment (Table 1). 
Decrease in plant height was found in case of 10 and 20 ppm treatments. Results of Hoque and Haq (1994) had revealed that seed inoculated with Rhizobium significantly increased plant height of lentil. Similar results of increase had also been reported by Togay et al. (2008) in chickpea. By applying $50 \mathrm{ppm} \mathrm{GA}_{3}$, maximum plant height was recorded in tomato (Kumar et al. 2014). However, application of $\mathrm{GA}_{3}$ decreased plant height in mungbean (Abdel and Al-Rawi 2011). Thus, these results are in agreement with those of previous workers who have observed that height of plant may increase or decrease depending on concentration of $\mathrm{GA}_{3}$ treatments.

Results also showed that number of primary branches per plant increased due to $50 \mathrm{ppm} \mathrm{GA}$ treatment whereas, number of secondary branches per plant responded negatively following all treatments. Previously Kumar et al. (2015) reported increased number of primary and secondary branches per plant following $\mathrm{GA}_{3}$ treatments in China aster. Application of Rhizobium inoculation and $50 \mathrm{ppm} \mathrm{GA}_{3}$ treatments had stimulating effect in shoot length although, length of root was found to decrease due to all treatments except 50 ppm GA . Reports of Nishita and Joshi (2010) had revealed that rhizobial inoculated plants gave significantly higher shoot length in chickpea. By applying $\mathrm{GA}_{3}$ treatment, Thakare et al. (2011) had found increased shoot and root length in chickpea.

Findings of this investigation indicated that the maximum fresh and dry weight of shoot was obtained due to $50 \mathrm{ppm} \mathrm{GA}_{3}$ treatment, however lowest was found in Rhizobium treatment. Similarly fresh and dry weight of root was also increased due to all $\mathrm{GA}_{3}$ treatments and maximum was found in case of $50 \mathrm{ppm}$ treatment (Table 1). Application of $\mathrm{GA}_{3}$ treatment had produced higher fresh and dry weight of shoot and root in chickpea (Iqbal et al. 2001). Results of Ogutcu et al. (2010) had revealed that bacterial inoculations significantly increased dry weight of root under both non-saline and saline conditions in chickpea. Results revealed that highest biomass duration per plant was obtained from the plants of $50 \mathrm{ppm}$ which was statistically at par with control (Table 1). Afrin (2015) obtained maximum value of biomass duration from 50 and 100 ppm $\mathrm{GA}_{3}$ treatments at early stage of tomato plant.

Table 2 shows that seeds treated with Rhizobium resulted maximum number of seeds per pod and 1000-seed weight although, the effect was rather negative in rest of the yield parameters due to the same treatment. Application of $10 \mathrm{ppm} \mathrm{GA}_{3}$ did not show any positive effect on yield contributing parameters. However, $\mathrm{GA}_{3}$ at $20 \mathrm{ppm}$ concentration resulted significantly higher number of pod, fresh weight of pods and number of seeds per plant than Rhizobium inoculation and $10 \mathrm{ppm} \mathrm{GA}_{3}$ treatment. Results also indicated that foliar application of $50 \mathrm{ppm} \mathrm{GA}_{3}$ had stimulating effect on number of pods per plant, fresh and dry weight of pods per plant, number of seeds per pods, number of seeds and straw yield per plant with significant responses in most of the cases. Here, plants obtained from $50 \mathrm{ppm} \mathrm{GA}$ treatment produced significantly higher fresh and

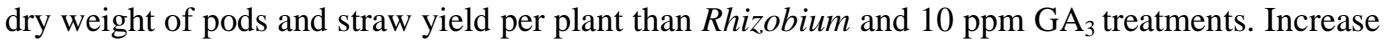
in number of pods per plant following $\mathrm{GA}_{3}$ treatments had also been reported by Mazid (2014) in chickpea. Nabi et al. (2014) had recorded higher number of pods, fresh and dry weight of pods per plant in cowpea. Zaman et al. (2011) had found increased number of seeds per pod in chickpea when soil treated with Rhizobium. Increase in 1000 -seed weight by using $\mathrm{GA}_{3}$ had also been reported by Akbari et al. (2008) in green gram.

Yield of BARI Chhola-9 obtained from 50 ppm $\mathrm{GA}_{3}$ treatment was $4.76 \%$ higher over the control. Increases in yield per plant following different concentrations of $\mathrm{GA}_{3}$ have also been noticed by many workers on various plants viz., chickpea (Choudhury et al. 2013), mungbean (Hoque and Haque 2002), green gram (Akbari et al. 2008), cowpea (Nabi et al. 2014). Harvest index was found to decrease due to Rhizobium and $\mathrm{GA}_{3}$ treatments which is not in agreement with the findings of other workers (Hoque and Haque 2002 and Nabi et al. 2014). 


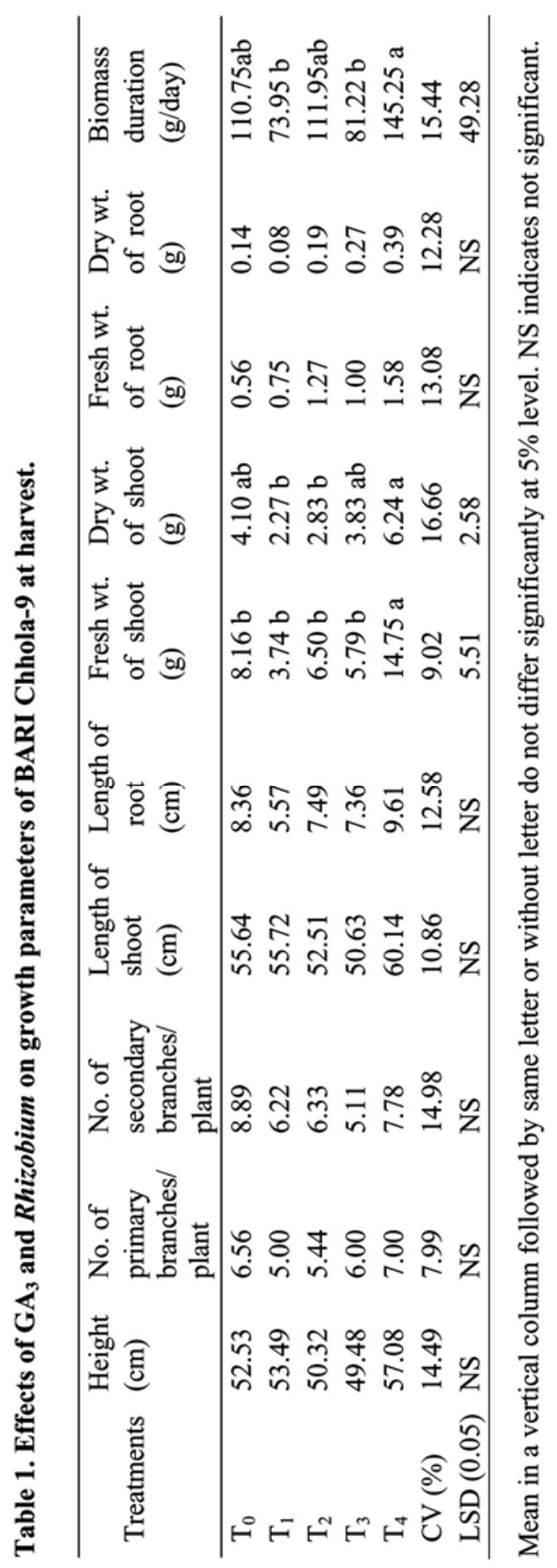




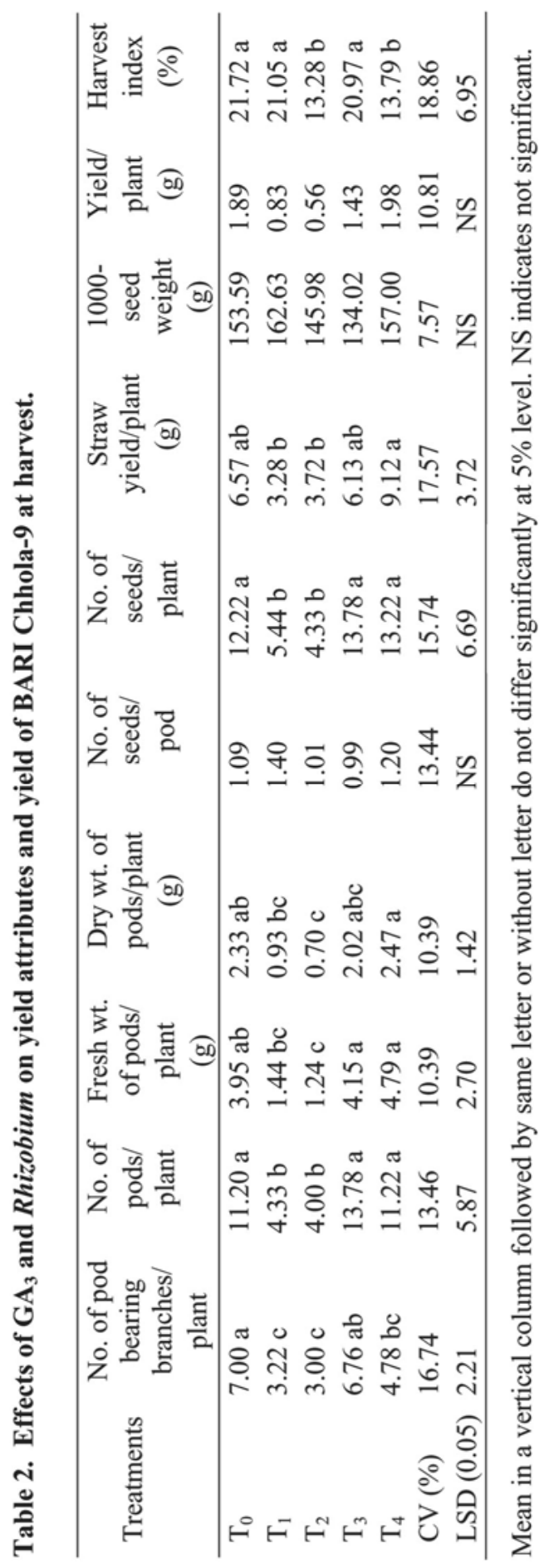


Results presented in Table 3 shows that chlorophyll a, b and carotenoids content of leaves increased due to $50 \mathrm{ppm} \mathrm{GA}_{3}$ treatment at both vegetative and flowering stages where, significantly higher amount of chlorophyll a and $\mathrm{b}$ were recorded from flowering stage although statistically similar to $20 \mathrm{ppm} \mathrm{GA}_{3}$ treatment. Chlorophyll a content of leaves was also found to increase due to Rhizobium inoculation and 20 ppm $\mathrm{GA}_{3}$ treatments but statistically at par with control. Results also showed that inoculation of Rhizobium and 10 ppm GA 3 treatments had almost negative responses to pigment content of leaves at both stages. Previously the positive effects of $\mathrm{GA}_{3}$ on the photosynthetic pigments had been reported in chickpea (Mazid 2014).

Table 3. Effects of $\mathrm{GA}_{3}$ and Rhizobium on pigment content (mg/g) of leaves of BARI Chhola-9 at two different stages.

\begin{tabular}{|c|c|c|c|c|c|c|}
\hline \multirow[b]{2}{*}{ Treatments } & \multicolumn{3}{|c|}{ Vegetative stage } & \multicolumn{3}{|c|}{ Flowering stage } \\
\hline & Chl.a & Chl.b & $\begin{array}{l}\text { Carotenoids } \\
\text { (mg/g) }\end{array}$ & Chl.a & Chl.b & Carotenoids \\
\hline $\mathrm{T}_{0}$ & $0.14 a b$ & $0.57 a$ & 7.58 & $0.04 b$ & $0.12 b$ & $5.94 a$ \\
\hline $\mathrm{T}_{1}$ & $0.17 \mathrm{ab}$ & $0.47 a b$ & 6.25 & $0.04 b$ & $0.10 \mathrm{~b}$ & $2.94 b$ \\
\hline $\mathrm{T}_{2}$ & $0.07 \mathrm{~b}$ & $0.25 b$ & 5.49 & $0.04 \mathrm{~b}$ & $0.08 b$ & $3.49 b$ \\
\hline $\mathrm{T}_{3}$ & $0.14 a b$ & 0.48ab & 6.59 & $0.09 \mathrm{ab}$ & $0.21 \mathrm{ab}$ & $5.16 \mathrm{a}$ \\
\hline $\mathrm{T}_{4}$ & $0.24 \mathrm{a}$ & $0.67 a$ & 8.49 & $0.14 \mathrm{a}$ & $0.27 \mathrm{a}$ & $6.12 \mathrm{a}$ \\
\hline CV (\%) & 51.81 & 40.84 & 22.44 & 82.79 & 63.94 & 32.09 \\
\hline LSD (0.05) & 0.10 & 0.26 & NS & 0.05 & 0.11 & 1.14 \\
\hline
\end{tabular}

Mean in a vertical column followed by same letter or without letter do not differ significantly at $5 \%$ level. NS indicates not significant.

Protein content of leaves increased following Rhizobium inoculation and 10 ppm $\mathrm{GA}_{3}$ treatments at vegetative stage and due to all treatment at flowering stage (Table 4). Foliar application of $\mathrm{GA}_{3}$ had stimulatory effect on protein content of leaves at vegetative and flowering stages of tomato (Afrin 2015). Increase in protein content of seeds was recorded from Rhizobium treatment only. By applying Rhizobium inoculation, Rabbani et al. (2005) had obtained increased protein content in pea seeds.

Table 4. Effects of $\mathrm{GA}_{3}$ and Rhizobium on protein content (mg/g) of leaves and seeds of BARI Chhola-9 at different stages.

\begin{tabular}{|c|c|c|c|}
\hline \multirow[t]{2}{*}{ Treatments } & \multicolumn{2}{|c|}{$\begin{array}{l}\text { Protein content of leaves } \\
(\mathrm{mg} / \mathrm{g})\end{array}$} & \multirow{2}{*}{$\begin{array}{c}\begin{array}{c}\text { Protein content of seeds } \\
\text { (mg/g) }\end{array} \\
\text { At harvest }\end{array}$} \\
\hline & Vegetative stage & Flowering stage & \\
\hline $\mathrm{T}_{0}$ & 0.93 & 31.88 & 127.56 \\
\hline $\mathrm{T}_{1}$ & 1.02 & 32.19 & 137.63 \\
\hline $\mathrm{T}_{2}$ & 1.13 & 36.75 & 125.75 \\
\hline $\mathrm{T}_{3}$ & 0.82 & 33.94 & 127.44 \\
\hline $\mathrm{T}_{4}$ & 0.76 & 44.56 & 64.75 \\
\hline CV(\%) & 27.05 & 41.82 & 15.91 \\
\hline $\operatorname{LSD}(0.05)$ & NS & NS & NS \\
\hline
\end{tabular}

Mean in a vertical column followed by same letter or without letter do not differ significantly at $5 \%$ level. NS indicates not significant. 
Findings of the present experiment indicate Rhizobium treatment substantially increase protein content of both leaves and seeds but reduced the yield considerably. On the other hand 50 ppm $\mathrm{GA}_{3}$ treatment increased the yield significantly but reduced the protein content of seeds drastically.

\section{References}

Abdel CG and Al-Rawi IMT 2011. Response of mungbean (Vigna radiata L. Wilczek) to gibberellic acid $\left(\mathrm{GA}_{3}\right)$ rates and varying irrigation frequencies. Int. J. Biosci. 1(3): 85-92.

Afrin S 2015. Effects of $\mathrm{GA}_{3}$ and IAA alone and in combination on BARI Tomato-14 (Lycopersicon esculentum Mill). M.Sc. Thesis, Department of Botany, Jagannath University, Dhaka. pp. 93.

Akbari N, Barani M and Ahmadi $\mathrm{H}$ 2008. Effect of gibberellic acid $\left(\mathrm{GA}_{3}\right)$ on agronomic traits of green gram (Vigna radiata L. Wilczek) irrigated with different levels of saline water. World Appd. Sci. J. 5(2): 199-203.

BBS (Bangladesh Bureau of Statistics) 2011. Yearbook of Agricultural Statistics of Bangladesh. Bangladesh Bureau of Statistics, Ministry of Planning, Government of the People's Republic of Bangladesh. Dhaka. pp. 512.

Bashan Y and de-Bashan LE 2005. Bacteria/plant growth-promotion. In: Hillel D. (Ed.), Encyclopedia of soils in the environment. Elsevier, Oxford, pp. 103-115.

Bhuiyan MAH, Khanam D, Hossain MH and Ahmed MS 2008. Effect of Rhizobium inoculation on nodulation and yield of chickpea in calcareous soil. Bangladesh J. Agric. Res. 33(3): 549-554.

Chowdhury MAH and Hasan MS 2013. Hand Book of Agricultural Technology. Bangladesh Agric. Res. Council, Farmgate, Dhaka. 230 p.

Choudhury S, Islam N, Sarkar MD and Ali MA 2013. Growth and yield of summer tomato as influenced by plant growth regulators. Int. J. Sust. Agri. 5(1): 25-28.

Dey R, Pal KK, Bhatt DM and Chauhan SM 2004. Growth promotion and yield enhancement of peanut (Arachis hypogaea L.) by application of plant growth promoting rhizobacteria. Microbiol. Res. 159: 371-394.

Fertilizer Recommendation Guide 2012. Bangladesh Agricultural Research Council, Farmgate, Dhaka-1215. pp. 274.

Golder PC, Sastry RK and Srinivas K 2014. Research priorities in Bangladesh: Analysis of crop production trends. SAARC J. Agric. 11(1): 53-70.

Hoque MM and Haq MF 1994. Rhizobial inoculation and fertilization of lentil in Bangladesh. Lens Newsletter 21: 29-30.

Hoque MM and Haque MS 2002. Effects of gibberellic acid $\left(\mathrm{GA}_{3}\right)$ on physiological contributing characters of mungbean (Vigna radiata L.). Pakistan J. Biol. Sci. 5(4): 401-403.

Hulse SH 1991. Nature, composition and utilization of grain legumes. In: Uses of tropical legumes: Proceedings of a consultant meeting 27-30 March, 1989. ICRISAT Centre Patancheru, AP 502-324, India. pp. 11-27.

Iqbal HF, Tahir A, Khalid MN, Haq I and Ahmad AN 2001. Response of chickpea (Cicer arietinum L.) growth towards the foliar application of gibberellic acid at different growth stages. Pakistan J. Biol. Sci. 4(4): 433-434.

Jackson ML 1973. Soil Chemical Analysis. Asia Pub. House, Bombay, Calcutta, New Delhi, Madras. pp. 151-154.

Kumar A, Biswas TK, Singh N and Lal EP 2014. Effect of gibberellic acid on growth, quality and yield of tomato (Lycopersicon esculentum Mill.). IOSR J. Agric. Veterinary Sci. 7: 28-30.

Kumar KP, Padmalatha T, Pratap M and Reddy SN 2015. Effect of plant bio-regulatores on growth, flowering and seed yield in China aster (Callistephus chinensis L. Nees) cv. kamini. Indian J. Agric. Res. 49(4): 348-352. 
Lowry OH, Rosebrough NJ, Farr AL and Randall RJ 1951. Protein measurement with folin phenol reagent. J. Boil. Chem. 193: 265-275.

Maclachalan S and Zalik S 1963. Plastid structure, chlorophyll concentration and free amino acid composition of a chlorophyll mutant of barley. Can. J. Bot. 41: 1053-1062.

Mazid M 2014. Seed priming application of gibberellic acid on growth, biochemical, yield attributes and protein status of chickpea (Cicer arietinum L. cv. DCP 92-3). Int. J. Genetic Eng. Biotechnol. 5(1): $17-22$.

Mckinney G 1940. Criteria for purity of chlorophyll preparations. J. Biol. Chem. 132: 91-107.

Murphy J and Riley JP 1962. A modified simple solution method for determination of phosphate in saturated water. Analytica. Chemica. Acta. 27: 31-36.

Nabi AJMN, Hasan MM, Alam MS, Islam MS and Islam MR 2014. Responses of gibberelic acid (GA $\left.A_{3}\right)$ on growth and yield of cowpea cv. BARI Falon-1 (Vigna unguiculata L.). J. Env. Sci. Natural Res. 7(2): 7-12.

Nishita G and Joshi NC 2010. Growth and yield response of chickpea (Cicer arietinum) to seed inoculation with Rhizobium sp. Nature Sci. 8(9): 232-236.

Ogutcu H, Kasimoglu C and Elkocae E 2010. Effects of rhizobium strains isolated from wild chickpeas on the growth and symbiotic performance of chickpeas (Cicer arietinum L.) under salt stress. Turk J. Agric. Forestry 34: 361-371.

Rabbani MG, Solaiman ARM, Hossain KM and Hossain T 2005. Effects of Rhizobium inoculants, nitrogen, phosphorus and molybdenum on nodulation, yield and seed protein in pea. Korean J. Crop Sci. 50(2): 112-119.

Steel RGD, Torrie JH and Dickey DA 1997. Principles and procedures of statistics. McGraw Hill Book Co. Inc. New York. 666 pp.

Thakare U, Patil N and Malpathak N 2011. Performance of chickpea under the influence of gibberellic acid and oxygenated peptone during germination. Adv. Biosci. Biotechnol. 2: 40-45.

Togay N, Togay Y, Cimrin KM and Turan M 2008. Effect of Rhizobium inoculation, sulfur and phosphorus application on yield, yield components and nutrient uptake in chickpea (Cicer aretinum L.). African J. Biotechnol. 7(6): 776- 782.

von Wettstein D 1957. Chlorophyll-lethal under Submikroskopisoche Formechse der Plastiden. Expt. Cell Res. 12: 427-507.

Zaman S, Mazid MA and Kabir G 2011. Effect of Rhizobium inoculatn on nodulation, yield and yield traits of chickpea (Cicer arietinum L.) in four different soils of greater Rajshahi. J. Life Earth Sci. 6: 45-50. 